\title{
The Instruction of Information Technology in the Education of Non-Commissioned Officers in Hungarian Law Enforcement
}

\section{Az informatika oktatása a magyarországi rendvédelmitiszthelyettes-képzésben}

The author of the article presents the current situation of the instruction of information technology in the education of non-commissioned officers (NCOs) in the Hungarian law enforcement organisation. A survey was conducted through a questionnaire to assess experiences, consequences and to make suggestions for further improvement.

Keywords: law enforcement, education, IT instruction, police, disaster management, prison service

A cikkben a szerző bemutatja a magyarországi rendészeti tiszthelyettesképzésben az IT-oktatás jelenlegi helyzetét. Egy kérdőíves kutatással felméri az oktatásban részt vevők ismereteit, véleményét. A cikk végén a kutatás és a kérdőíves felmérés alapján összegzi a tapasztalatokat, következtetéseket von le, továbbá oktatásfejlesztési javaslatokat tesz.

Kulcsszavak: rendvédelem, oktatás, informatikaoktatás, rendőrség, katasztrófavédelem, büntetés-végrehajtás

\section{Introduction}

From a historical perspective, we can certainly claim that no matter which domain of life is affected, success can mostly be traced back to the improvement and more 
effective organisation of trainings and instruction. In his writing dating back to the $5^{\text {th }}$ century, Epitome rei militaris [Concerning Military Matters], the Roman Vegetius emphasised the importance of training with the following words: "He who wants victory, let him train soldiers diligently" [24: 797]. This fundamental principle also characterised the military history of the Middle Ages, as armies consisting of regular, well-trained units proved to be simply more successful [1].

As time passed, training became increasingly important since specialised skills were necessary in basically every domain. This phenomenon is rooted partly in the complexity of the world and the way it works, partly in the necessity of the practical application of the novel technical-technological advances. However, the structure of instruction and of an up-to-date curriculum can hardly keep pace with the rapid technological development. This statement especially applies to the field of information technology. Compared to other professions, it becomes quite obvious that technological novelties used to serve humanity for a generation, but in the area of information technology, development can be measured in cycles of only 3 to 6 years. As a consequence, skills acquired 5-10 years ago are already outdated, while in other professions competences can be made use of much longer. This applies to specialists as well as to users. Information technology is part of our everyday life, in fact, increasingly so. Thus is it absolutely essential that law enforcement studies should also entail a training in it.

Governments, ministries, the relevant bodies of the European Union have also taken measures regarding the field of IT studies. The recommendation of the European Parliament and Council issued on 18 December 2006 stresses the importance of key competences necessary for life-long learning [2: 4]. Consequently, the National Curriculum of Hungary also defines the key competences, including digital skills [3: 10-11]. In 2015, the Hungarian Government launched a package with the title Digital Welfare Programme, which formulated the need of a Digital Education Strategy and its presentation to the government [4: 3]. In 2016, the Government adopted the Digital Education Strategy [5: 1], which defines its focus as follows:

"By now the use of digital technologies has become an integral part of our everyday lives and most work processes, therefore, it is an essential economic and social requirement that the school should prepare students for the use of digital technologies and devices at the level of competence. In spite of this trend, however, in Hungary more than one third of the population aged 15 or older are digitally illiterate and most of them are threatened by the digital divide. The employability of workers who cannot use digital devices and applications is declining from day to day, and so is the competitiveness of companies refusing to join the digital world" [6: 28].

An important work focusing on the training of NCOs is István Bökönyi's dissertation [7]. This work written in 1987 describes the training history of law enforcement NCOs and outlines future improvement options. Bökönyi emphasised the importance of an independent training institution for NCOs and stressed the significance of the instruction of computer skills and foreign languages. The outlined paths of development - considering the date of release - proved rather forward-looking, and now we know that the author accurately recognised the real demands of the future. 
In this paper, I will present the NCO training in three Hungarian law enforcement areas: the police, disaster recovery and prison service. Besides, I will also explore the current situation of the instruction of information technology, demonstrating how information technological solution plays a growing role in the various activities of law enforcement. Based on the above mentioned facts, a preparative training for the application of IT devices and systems can fundamentally influence the professional effectiveness of law enforcement organisations.

\section{Modular Training}

Until quite recently, the three bodies in focus conducted their internal training according to their own unique systems. It was mainly due to the fact that each one of them was under the control of different authorities, operated in differing structures and had a different legal status. The police operated - as its largest organisation - as part of the Ministry of the Interior. On 29 June 2006, the Ministry of the Interior ceased to exist, and its responsibilities were partly taken over by the Ministry of Local Government and partly by the Ministry of Justice and Law Enforcement until the Ministry of the Interior was re-established in 2010. In the period between 2006 and 2010, the police were controlled by the Ministry of Justice and Law Enforcement.

Prison service was governed by the Ministry of Justice from the 1970s onwards, but from 2006, it was also moved under the control of the Ministry of Justice and Law Enforcement. In 2010, the newly established Ministry of the Interior got in charge of the prison service, as well [8: $37 \S d]$.

The Fire Service, then Department of Disaster Recovery used to belong partly to the Ministry of the Interior, partly to local councils. Its structure was neither consistent nor operated in a strictly hierarchical way. Not only its structure but also its responsibilities got fundamentally changed by the act on disaster recovery which entered into effect in 2012 [9: 22-24 §].

Since 2010, all three organisations have been under the umbrella of the Ministry of the Interior, and thanks to this, legal acts and provisions governing their activities - more specifically their training duties - are also partly identical.

One of the main goals set by the newly established Ministry of the Interior was the transformation of the training system, which would - among other things - allow transition from one profession to another within law enforcement. In December 2010, a government decision was issued on the new modular training system of the law enforcement organisations [10]. In practice, it translates into a training system consisting of general and specific professional modules. According to this new concept, each law enforcement organisation provides a foundation for the competences of their personnel with the same general module. Having completed that, they can move on to more specific modules connected to the basic responsibilities of their individual organisation. Today, the training system of all three organisations is modular, and all applicants must have passed their secondary school final exams. 


\section{Training System in the Police Forces}

In Hungary, four educational institutions are in charge of the training of NCOs in the police forces. I will present the curriculum - with specific focus on the instruction of information technology - of secondary schools for aspiring police officers by analysing the curriculum of the Vocational School of Law Enforcement in Körmend. These schools provide qualification for aspiring police NCOs after their secondary school final exams; their operation is regulated by the Act on National Public Education [11].

The school in Körmend has 22 general and 8 specialised classrooms. Out of the 8 specialised classrooms, 4 are computer labs [12: 17]. The qualification period lasts for two years and fits into the public education system. The two years contain five modules in total:

- Core Duties in Law Enforcement

- Duties of Assistant Patrolling Officers

- Team service

- Patrolling Duties

- Maintenance of Public Order, Border Control, Traffic Management or Crime Prevention and Investigation (according to the specialisation of the students' choice)

The enumeration clearly shows that out of the five modules only the fifth differs, the remaining four are the same for all law enforcement students. During the 4-term training, the total number of classes is 2,506 [12: 83], the course being equally split between $50 \%$ theory and $50 \%$ practice. In the module Core Duties in Law Enforcement, there are ten school subjects in 370 lessons in total [12: 175-176]. Information Technology I comprises 20 lessons divided into 6 lessons of Basic IT in Law Enforcement and 14 lessons of Basic Telecommunication. The rough outline of the curriculum of the above subjects is the following:

Basic IT in Law Enforcement:

- The significance of information technology in the various fields of law enforcement, interrelatedness of information technology and crime.

- Basic terminology in information technology, the definitions of information and data.

- Computer systems, hardware and software.

- Use of the school computer network and of the distance learning system.

Basic Telecommunication:

- General telecommunication skills, the construction, use and application rules of the TETRA network EDR (Unified Digital Radio Communications System) [12: 181].

In the module Duties of Assistant Patrolling Officers, we find 13 subjects in 524 lessons: Information Technology II in 48 lessons [12: 184-185]. Its rough curriculum outline is the following:

- Basic word processing skills, typing, formatting (20 lessons). 
- Registration and management programmes in law enforcement (Robotzsaru Neo, HERR, HERMON and SIS - 8 lessons).

- Use of the documentation management and the case handling programme of the police force "Robotzsaru Neo" (20 lessons) [12: 184].

The Team Service module comprises 12 subjects in 344 lessons: Information Technology III takes up 12 lessons [12: 196-197]. The material focuses on the practice of "Robotzsaru Neo" and its better and deeper understanding [12: 200].

The module Patrolling Duties contains 552 lessons in total split into 16 subjects: Information Technology IV takes up 8 lessons [12: 205-206] and concentrates on the generation of documentation management in the maintenance of law and order in "Robotzsaru Neo" [12: 215].

The specialised fifth module comprises 556 lessons in all four fields [12: 217-218, 227-228, 239-240, 251-252], and information technology is instructed in 12 lessons with specialised material content [12: 225, 236-237, 248, 260].

In total, information technology is taught in 100 lessons, which are distributed to five modules. Information technological systems and infrastructure are targeted only in the first two modules: in Information Technology I and II IT skills gradually become inherent parts of other subjects, in particular of subjects relevant to border control (e.g. NEKOR, FADO, iFADO, PRADO, SIS, VIS). In police schools, all subjects connected to information technology - besides Information Technology I and II - are taught by IT specialists. As some of the material may have been acquired during the students' early studies in public education, I personally believe that the curriculum of the information technology courses could already be based on previously acquired knowledge and skills. I also endorse the instruction of IT skills in the fields of IT security and corporate IT systems.

\section{Training System in the Prison Service}

Virtually, throughout its entire history, the organisation of prison service operated its own internal training system. Today courses are held at the Further Training and Conference Centre of the Prison Service.

In 2010, upon the initiative of the Ministry of Interior, the Government set the new goal of a uniform training system for all law enforcement organisations [13]. Following the development and adoption of the new qualification system, the newly established penitentiary professions showed up in the National Qualification Registry.

While making the training more up-to-date, the training system of the prison service remained outside the education system due to professional considerations. The duration and the structure of the training in prison service are established in a way that the subsequent modules in a logical order already form a part of the qualification.

In this still functioning modular system, the first module of Core Duties in Law Enforcement is directly followed by specialised modules, such as Prison Guard Service, Assistant Prison NCO, then Prison NCO. If these are completed successfully, students must pass a complex professional test which will eventually provide them with their 
full qualification. The instruction period of the four modules is 27 -week long and covers 870 lessons in total: out of these 522 focuses on theory, while 348 are practical classes. Students take part in 690 lessons at school and in 180 practical lessons in prisons [14: 7]. Information technology is instructed in 16 lessons only in the first module within the framework of Basic Telecommunication [14: 10]. The institution has a computer lab necessary for the instruction [14: 20], which is based on the notes prepared by the instructor [15]. The notes are well-structured, the material is informative and corresponds to the number of classes. The contents are the following:

- Regulations of IT Security

- Basic IT skills (computer skills, internet use, word processing, creating tables and presentations, etc.)

- IT Security (basics, viruses, the IT systems in prison service)

- IT systems in prison service (software, hardware, network infrastructure)

- The radio communications system "EDR"

Work-related computer training is also conducted in later modules. Students learn about the structure and operation of the security system within the framework of the subject Security and also during practical classes in prisons.

Again, having seen the contents of the school material, we see that - similarly to the IT training of the police forces - the material covers skills that students must or may have acquired previously in public education.

\section{Training System in Disaster Management}

The main responsibilities of disaster recovery consist of an ever-increasing number of part activities. Today's organisation of disaster management is based on the organisation of the fire service, thus its training is also based on that of professional fire fighters, which dates back in Hungary to 150 years [16: 8-9]. Their training institution has been called the Disaster Management Training Centre (KOK) since 2000. Since 2008 , the training has had a modular structure, which brought rather large-scale changes to the training structure, to the teaching and learning process as well as to the examination procedure. The general transformation of law enforcement training in 2010 also affected the training system of the KOK.

The training consists of three modules: the first - as in the other two law enforcement organisations - is Core Duties in Law Enforcement. A part of the instruction of this module is not carried out in the KOK but in law enforcement vocational schools. Out of the three months, the students of disaster recovery attend their classes (in total 250 lessons) for two months alongside policing students in law enforcement schools. In the third month, however, in 130 lessons, they receive specialised instruction. The second and third modules last for two months each. The entire training duration is 7 months. Consequently, the contents of the school material resemble that of the students of prison service. Information technology is taught within the framework of the uniform Core Duties in Law Enforcement with the 20 lessons in Information Technology I. Further IT training is also part of the module Fire Service II. The subject 
Communication of Information comprises 12 lessons out of the module of 276 lessons in total. As far as its material is concerned, it concentrates on wired and wireless communication, with special focus on the structure, operation and practical use of the radio network system EDR. In the module Fire Service I (283 lessons), students do not receive further instruction in information technology. All in all, students trained in fire service receive IT instruction in only 32 lessons.

\section{Information Technology in Public Education}

Today, information technology skills can primarily be acquired in elementary and high schools, I have therefore investigated its current application, curriculum and situation in public education. Before 1990, the instruction of information technology was divided into several parts, and the term "information technology" was not used at all. The instruction of wired and wireless communication, however, has a past of several decades and an important present in technical secondary and higher education as well as higher-level military training.

From the 1960s, computer skills were mainly taught in higher education specialised in technology or economy. Secondary-level computer instruction was carried out in special IT-specialised vocational schools. In the second half of the 1980s and in the early 1990s, more and more elementary and high schools launched extra-curricular IT-related courses, which enriched the education range of information technology. At the time, programming represented the backbone of IT-instruction, especially the programming language Basic [17: 34-41].

In 1995, the National Curriculum of Hungary was adopted, which - as a novelty - contained digital literacy. According to the curriculum, the instruction of information technology had to be introduced in junior high schools. The material stressed the importance of user-oriented programmes, such as the word processor, creation and management of charts and tables [18: 47]. However, the introduction of IT-studies was not entirely successful, as there was neither a sufficient number of computers nor enough specialised teachers.

The infrastructural foundation of the instruction of information technology was supplied by the SuliNet programme announced in 1996 and launched in the school year of 1997/1998. Within its framework, internet access was provided first to high then to elementary schools, and in total, 11 thousand new computers got installed in schools [19: 29].

In addition to the provision of the assets, it was also an important step that the framework curriculum was passed as a law, which ensured new perspectives from the school year of 2001/2002 onwards. In summary, we can establish that the compulsory instruction of information technology began between 1998 and 2001 in elementary and high schools. Thus, children born in 1984 had the opportunity to study IT if they wanted to, while those born after 1988 had to study IT in public education.

Presently, the mandatory number of classes is governed by the Act issued by the Ministry of Human Resources in 2012 on the rules of issuing and approval of framework curricula [20]. The framework curriculum for the years 5 to 8 of elementary 
schools defines "digital competences" among the key competences and competence development aims, as follows: "Students become increasingly motivated to use ICT-devices. They are capable of using basic computer applications (word processor, data handling) during their curricular and extra-curricular activities as well as in their everyday life. With increasing confidence, they are able to make use of the information provided by computers and the internet, even in collection tasks according to given criteria" [21: 6]. In accordance with the framework curriculum, information technology is a compulsory school subject in the $6^{\text {th }}$, the $7^{\text {th }}$ and the $8^{\text {th }}$ grades of elementary school in 1 lesson/week, which comes to 36 lessons per school year [21: 8-10]. The school material focuses on the importance of problem solving and regards the proficient use of user programmes as essential [21: 654-660].

In grammar schools, information technology is taught in 1 lesson/week in the years 9 and 10 (which makes 36 lessons a year) [22: 9-11]. The curriculum concentrates on the use of applications, internet literacy and its efficient use, but the emphasis is again on problem solving with the use of IT in the most various domains [22: 578-600]. In vocational schools, the framework curriculum regards digital competences as a key competence, similarly to the framework curriculum of grammar schools [23: 5]. The number of IT lessons in vocational schools can differ, however, from that of grammar schools, depending on its specialisation, but it can be established that in the majority of vocational schools, information technology is a compulsory subject in at least 2 lessons/week in the years 9 and 10, which adds up to 72 lessons a school year [23: 8-18]. The description of the material is roughly identical with that in the grammar school curriculum [23: 694-711].

\section{Questionnaire Survey}

In order to be able to assess the information technology training of NCOs in law enforcement, in 2018 I conducted a questionnaire survey with the participation of 122 policing students, 98 prison service students and 98 disaster management students. The questionnaire listed 16 questions, which focussed on previous training in IT, previously acquired IT-skills and on the IT-infrastructure of law enforcement organisations in addition to statistics-related questions.

Nearly three-quarters of the participants were male in the police forces, in the prison service the ratio of men and women was $57 \%-43 \%$, while in disaster recovery, all participants (100\%) were male. There are serious differences in age between the three organisations, see below: 

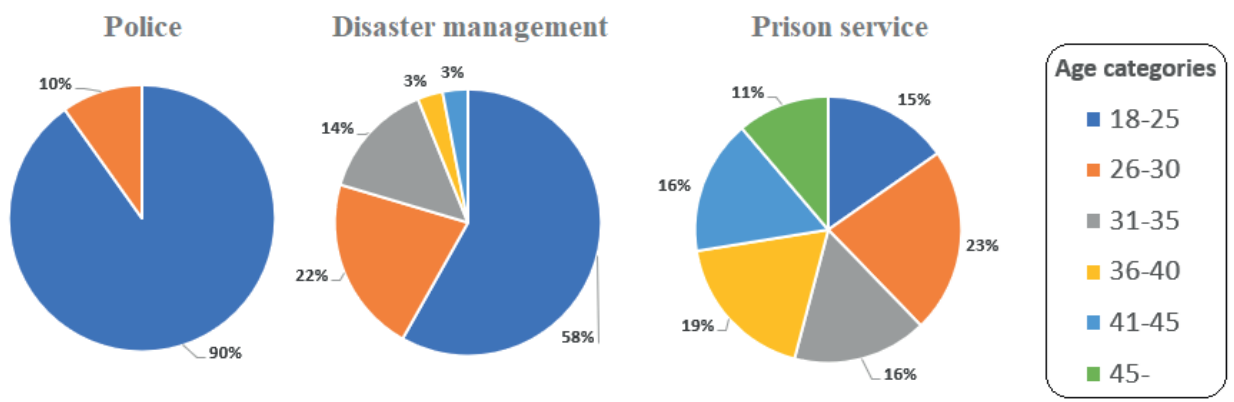

Figure 1.

Distribution of students by age [Compiled by the author.]

In the police forces, it is quite typical that students move on to the policing vocational schools right after their secondary final examination. Among disaster management students, age distribution is more varied, but there are only a few students over 35 years of age due to the demanding physical requirements. In prison service, all age groups are present in significant numbers.

Based on the answers to my questions, I could establish that the great majority of the participants have the necessary devices to access digital services (PC, laptop, smart phone, tablet) supplied with a wired and/or mobile broadband internet connection. $92 \%$ of the informants had studied information technology at school $100 \%$ of policing students, $98 \%$ of the disaster recovery students and $78 \%$ of prison service students). The differences result from the varying age distribution. About $16 \%$ of the informants had passed a secondary final exam in information technology, and most of the participants had felt satisfied with the available computing devices, the informativeness of the teachers and the quality of the material.

It is due to the age difference that $95 \%$ of the prison service students had had a job before, and $80 \%$ of them would have used computers. Having explored the students' user habits, we can see that most of them use the internet to reach social media sites, manage their email correspondence or read the news and access other information. Most of the participants have already done shopping online. Financeand public services-related issues are mostly managed online by those who run their own household.

The majority of the informants of the survey regard their word processing, table and presentation creating skills at least average or, more often, good. On the other hand, regarding corporate network systems and security, they deem their skills poor, as also reflected by the questions focusing on IT systems and products. All participants agreed that information technology was crucial for their jobs, and IT-related training was completely essential.

In public education, the instruction of information technology has been obligatory since 2001, but most of the elementary and high schools had started giving IT courses before that. Students take three years of information technology in elementary and 
two years in high school, but most schools exploit their possibilities and extend their IT-instruction.

As a result, most students who study to be NCOs in law enforcement have taken IT lessons in public education. Those applicants who wish to work in law enforcement, have begun their relevant training and are older than 35, have almost invariably held a job before, where most of them would have used IT devices and systems, thus they also do have basic computer skills. My questionnaire survey conducted in the training of NCOs also supports my statements.

Based on the above claims, I conclude that the instruction of basic competences in information technology (word processing, creating tables and presentations, use of operation systems, internet literacy and online search, etc.) is not at all necessary unless for helping candidates with poorer skills (established through a placement test) to catch up. However, with the quick-paced technological development and extended use of technology, the instruction of corporate IT-systems and IT-security would be essentially important, including the management of unusual events (reporting, error detection and localisation or reduction of damage).

\section{Conclusion}

In this paper I demonstrated that information technology is completely indispensable in all domains of life. Consequently, fewer and fewer jobs can be performed without computer skills. Law enforcement is no exception. I therefore decided to carry out an analysis of the training of NCOs, more specifically, their training in information technology.

The law enforcement training has been made uniform and modular by the Ministry of Interior, yet the training of policing students still greatly differs from that of students of prison service and disaster recovery. Having studied the school subjects, I established that information technology is taught in several of them. The activities, administration performed by IT devices or systems in a specific area should be instructed within or connected to the subject relevant to the given area by a specialist. The reason for this is that professional and specific areas do not change but, because of the technological development, the platforms of the collection, processing, forwarding and servicing of data and information do (see digital technology instead of an analogue one, IT devices or systems instead of paper).

I conducted a questionnaire survey among law enforcement students with the main conclusions that most students enter the training with IT-skills previously acquired in public education. They, however, do not have sufficient knowledge of IT-security and corporate IT-systems. Comparing this with the IT-instruction in elementary and high schools, I concluded that a part of the IT-training could be omitted and more advanced IT-related topics should be taught instead. The changes that I suggest in this paper serve a better quality IT-training provided to the students of vocational schools of law enforcement. 


\section{References}

[1] B. Kákóczki, "Az „Epitoma” hatása a középkori (had)tudományos irodalomra," PhD dissertation, University of Debrecen, Doctoral School of History and Ethnography, Debrecen, 2012.

[2] Recommendation 2006/962/EC of the European Parliament and of the Council of 18 December 2006 on key competences for lifelong learning (16 December 2006).

[3] A. Abonyi-Tóth and M. Turcsányi-Szabó, A digitális írástudás fejlesztésének lehetöségei. Budapest: Educatio Kft., 2015.

[4] Digital Welfare Programme of the Hungarian Government, based on Government Resolution 2012/2015 (XII. 29.) and the results of the national consultation on the internet and digital development projects (InternetKon).

[5] Government Resolution 1536/2016 (X. 13.) on the digital reform of public education, vocational education, $\mathrm{HE}$ and adult training system and on the Hungarian Digital Education Strategy

[6] The Digital Education Strategy of Hungary, Supplement of the Government proposal, Budapest, 2016.

[7] I. Bökönyi, "A rendőr tiszthelyettes- és zászlósképzés felszabadulás utáni története, helyzete, fejlesztésének lehetőségei," dissertation, Miklós Zrínyi Military Academy, Budapest, 1987.

[8] Government Decree 212/2010 (VII. 1.) on the scope of activities and competence of the individual ministers and the State Secretary heading the Prime Minister's Office.

[9] Act CXXVIII of 2011 on the amendment of the Act on Disaster Management and of other Acts in relation.

[10] Government Resolution 1282/2010 (XII. 15.) on the measures necessary for the uniform modular training system of law enforcement organisations.

[11] Act CXC of 2011 on National Public Education.

[12] Curriculum of the Vocational School of Law Enforcement in Körmend (Körmend, 2017).

[13] Government Resolution 1282/2010 (XII. 15.) on the measures necessary for the uniform modular training system of law enforcement organisations.

[14] "Iskolarendszeren kívüli büntetés-végrehajtási felügyelő szakképesítés képzési programja," [Qualification training programme of prison officers outside the education system], identification number OKJ 52861 02, BVOTRK, 2016.

[15] B. Tuba Kovács, "Büntetés-végrehajtási informatikai ismeretek," notes, 2017.

[16] I. Berki and Á. Berkiné Ványi, Eds., A Katasztrófavédelmi Oktatási Központ ésjogelőd szervezeteinek hét évtizedes története. Budapest: Disaster Management Training Centre, 2018.

[17] Á. Nagy, "Információs írástudás és informatikai intelligencia. Az informatika oktatás paradigmaváltásai Magyarországon," Új Pedagógiai Szemle, vol. 50, no. 4, 2000. 
[18] B. Czékmán and P. Fehér, "A számítógéppel támogatott tanítás és tanulás története a közoktatásban Magyarországon (1983-2016)," Képzés és Gyakorlat, vol. 15, no. $1-2,2017$.

[19] I. Kónya, "Az informatika fejlődése a magyar közoktatásban," M. A. thesis, University of Debrecen, Faculty of Information Technology, Debrecen, 2007.

[20] Ministerial Decree 51/2012 (XII. 21.) of the Ministry of Human Resources on the rules of issuing and approval of framework curricula.

[21] Framework curriculum for grades 5-8 of elementary schools, Appendix 2 of Ministerial Decree 51/2012 (XII. 21.) of the Ministry of Human Resources.

[22] Framework curriculum for grades 9-12 of high schools, Appendix 3 of Ministerial Decree 51/2012 (XII. 21.) of the Ministry of Human Resources.

[23] Framework curriculum for grades 9-12 of vocational schools, Appendix 14 of Ministerial Decree 51/2012 (XII. 21.) of the Ministry of Human Resources.

[24] I. Hahn, ed., A hadmüvészet ókori klasszikusai. Budapest: Zrínyi Katonai Kiadó, 1963. 